\title{
Fate of Bacteriophage $\lambda$ DNA After Adsorption by Haemophilus influenzae
}

\author{
By CAROL M. NEWMAN* AND J. H. STUY \\ Department of Biological Science, \\ Florida State University, \\ Tallahassee, Florida 32306, U.S.A.
}

(Accepted for publication 4 December 1970)

SUMMARY

\begin{abstract}
Radioactively labelled coliphage $\lambda$ DNA is rapidly and irreversibly bound by competent bacteria of certain cultures of Haemophilus influenzae. The extent of adsorption in the presence of excess cells was always between 30 and $40 \%$ of the DNA added. Bound DNA was rather resistant against degradation to acid-soluble products but the biological activity was completely lost after 60 min. incubation. Reisolated phage $\lambda$ DNA always banded in $\mathrm{CsCl}$ gradient centrifugation at a position characteristic for double stranded $\lambda$ DNA. It sedimented with normal or slightly reduced velocity in sucrose density gradients. Production of $\lambda$ phage or of infectious phage $\lambda$ DNA was not observed.
\end{abstract}

\section{INTRODUCTION}

Competent Haemophilus influenzae bacteria of strain Rd are capable of very rapidly adsorbing transforming DNA (Stuy \& Stern, 1964). Adsorbed DNA is partially degraded to acid-soluble products, most of which, if not all, are found in the medium (Stuy \& van der Have, 1971). Steinhart \& Herriott (1968) have studied the uptake of foreign Escherichia coli DNA by $H$. influenzae and found that it is not completely broken down nor is it integrated into the recipient genome. There has been some doubt whether $H$. influenzae can bind foreign DNA (Schaeffer, 1958) but low competency may explain those results. Lacks, Greenberg \& Carlson (1967) reported that Diplococcus pneumoniae can adsorb heterologous DNA, thus confirming an earlier finding by Lerman \& Tolmach (1957). Irreversibly bound E. coli DNA is rapidly degraded, however, presumably by exonuclease action (Lacks et al. 1967). On the other hand, Pene \& Romig (1964) reported that Bacillus cereus DNA irreversibly bound by B. subtilis does not seem to be broken down nor is it integrated. In the light of these variable observations, we wished to re-examine the uptake of foreign DNA by $H$. influenzae and specifically to verify whether this process is similar to the uptake of homologous DNA. We were also interested in possible expression of bound foreign DNA. We chose bacteriophage $\lambda$ DNA for our studies because many of its properties are well known. We found that different cultures of strain Rd show considerable variation in irreversible binding of phage $\lambda$ DNA but that there is no production of whole phage or of infectious phage $\lambda$ DNA.

* Present address: Department of Health, Education and Welfare, Communicable Disease Center, Atlanta, Georgia 30333, U.S.A. 


\section{METHODS}

Cultures. Escherichia coli cultures were strain c600 (obtained from Dr A. D. Kaiser) and $\mathrm{c} 600\left(\lambda \mathrm{imm}^{434} \mathrm{susN}\right.$ ) (a gift from Dr B. J. Barnhart). Phage $\lambda$ ind-c I 857 (obtained from Dr R. A. Weisberg) was used to lysogenize $E$. coli $\mathrm{C} 600$ and a $\lambda$-resistant mutant was isolated.

Haemophilus influenzae strain Rd cultures were wild-type 62 and its novobiocinresistant (nov-r) derivative 66. Wild-type $\mathrm{Rd} \mathrm{I} 43$ and $\mathrm{Rd}^{\left(\mathrm{HPI}^{+}\right)} \mathrm{I} 38$ were a gift from Dr C. S. Rupert. All other cultures are derivatives from 143 prepared by lysogenization and/or transformation. In our laboratory, cultures mutate very frequently to phage resistance (Stuy, I968).

Media. TB was I $\%$ Tryptone broth with $0.5 \% \mathrm{NaCl}$. TA was $\mathrm{I} \cdot 5 \%$ agar in TB. Soft TA contained $0.7 \%$ agar. NTB was 2 vol. of I $\%$ Neopeptone broth with $0.5 \% \mathrm{NaCl}$ and I vol. TB. Other media have been described (Stuy, 1969).

Phage production. Radioactive phage $\lambda \mathrm{C}$ i 857 was produced by growing a culture of $\mathrm{c} 600 \lambda$-res $(\lambda \mathrm{Cr} 857)$ in NTB at $30^{\circ}$ until the viable count reached $3 \times 10^{8} / \mathrm{ml}$. The suspension was heated at $45^{\circ}$ for $15 \mathrm{~min}$. and carrier-free [ $\left.{ }^{32} \mathrm{P}\right]$ phosphate was added to give $30 \mu \mathrm{ci} / \mathrm{ml}$. It was then shaken at $37^{\circ}$ until lysis occurred. Lysates usually contained 5 to $7 \times 10^{10}$ plaque-forming units (p.f.u.) $/ \mathrm{ml}$.

Phage $\lambda \mathrm{imm}^{434}$ sus $N$ was prepared by inducing TB-grown cultures at $4 \times 10^{8}$ viable centres $/ \mathrm{ml}$. of lysogenic c 600 with $800 \mathrm{erg} / \mathrm{mm}^{2}$. of ultraviolet radiation. Lysates contained 3 to $5 \times$ Io ${ }^{10}$ p.f.u. $/ \mathrm{ml}$.

Phage HP1 was prepared as reported earlier (Stuy, 1969).

Preparation of phage DNA. Phage $\lambda$ was purified by centrifugation at $25,000 \mathrm{rev}$./min. for $60 \mathrm{~min}$. in a Spinco SW 25 rotor and resuspending in phage saline $(0 \cdot \mathrm{I} \mathrm{M}-\mathrm{NaCl}$, $3 \mathrm{mM}^{-\mathrm{MgSO}_{4}}, \mathrm{I} \mathrm{mM-CaCl}, 0.0 \mathrm{I} \%$ gelatin, $\mathrm{pH} 6.5$ to 7.0 ). $\mathrm{CsCl}$ was added to give a specific density of $1.45 \mathrm{~g} . / \mathrm{cm}^{3}$. After centrifugation at $36,000 \mathrm{rev} . / \mathrm{min}$. for $48 \mathrm{~h}$. in a 40.2 rotor, the visible phage band was collected in $2 \mathrm{ml}$. of SSC $(0.15 \mathrm{M}-\mathrm{NaCl}$, $0.015 \mathrm{M}$-sodium citrate), and an equal volume of freshly distilled and SSC-washed phenol was added. The suspension was gently rotated in the cold for $15 \mathrm{~min}$., after which the phenol was removed by centrifugation. The supernatant was dialysed against $0^{\circ} \mathrm{I} \mathrm{M}-\mathrm{NaCl}$. Preparations were used immediately. Their radioactivity was always about I c.p.m. $/ \mathrm{IO}^{6}$ phage $\lambda$ DNA molecules.

Phage HP1 DNA was prepared from suspensions of phage that had been partially purified by centrifugation only.

Preparation of competent bacteria. This has been described for Escherichia coli by Barnhart (1965) and for Haemophilus influenzae by Stuy \& van der Have (1971).

Biological assays. Phage $\lambda$ was scored at $37^{\circ}$ by plating with TB-grown cultures of Escherichia coli $\mathrm{C} 600$ in soft TA on TA plates. Phage HPl was assayed as reported by Stuy (1968).

Phage $\lambda$ DNA biological activity was determined as described by Barnhart (I965). This procedure is a modification of the original procedure by Kaiser \& Hogness (I960). Uptake of phage $\lambda$ DNA had to be carried out in suspensions of Escherichia c600, preinfected with helper phage $\lambda \mathrm{imm}^{434}$, containing less than Io $\mathrm{mM}-\mathrm{NaCl}$ and I mM$\mathrm{CsCl}$. Half of the biological activity was lost in the presence of ro $\mathrm{mM}-\mathrm{CsCl}$. Biological activity was always found to be about I p.f.u./ $10^{6} \lambda$ DNA molecules.

Transforming bacterial DNA of Haemophilus influenzae was assayed as described 
(Stuy, I962). Phage HP1 DNA was scored in the prophage transformation system (Stuy, 1969). In this assay, defectively lysogenic recipient bacteria are transformed to wild-type lysogenic ones by either wild-type phage HP1 DNA or by wild-type lysogen DNA. The efficiency of this process is about I p.f.u./I6 phage HP1 DNA molecules.

Adsorption of phage $\lambda$ DNA. Purified radioactive phage $\lambda$ DNA was added to competent Haemophilus influenzae cultures at $10^{9}$ viable centres $/ \mathrm{ml}$. The suspension was gently shaken at $30^{\circ}$ for $3 \mathrm{~min}$. and then quickly chilled in an ice-water bath. The bacteria were centrifuged in the cold. Reversibly bound DNA was removed either by washing the cells with $\mathrm{I} \mu \mathrm{g} . / \mathrm{ml}$. of pancreatic DNase in $\mathrm{O} \cdot \mathrm{I} \mathrm{M}-\mathrm{NaCl}$ containing

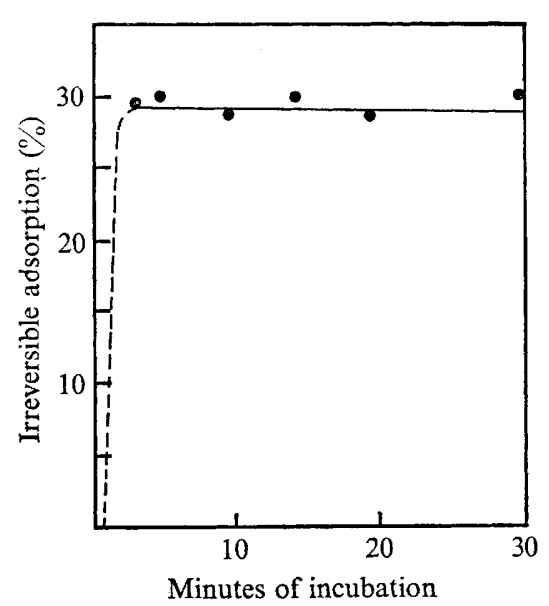

Fig. I

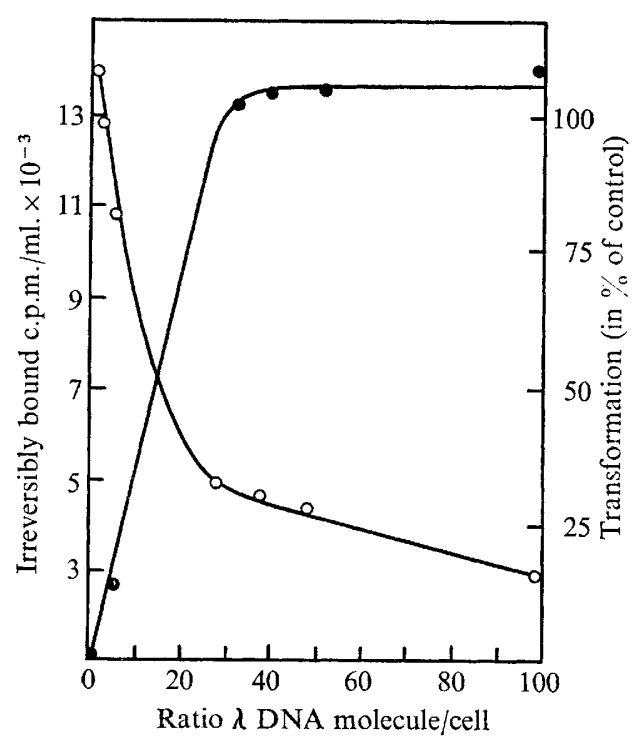

Fig. 2

Fig. I. Kinetics of irreversible adsorption of phage $\lambda$ DNA by Haemophilus influenzae Rd culture 66 at a ratio of one DNA molecule/bacterium.

Fig. 2. Saturation binding after $15 \mathrm{~min}$. exposure of Haemophilus influenzae Rd culture 66 to phage $\lambda$ DNA (O) and subsequent transformation by excess bacterial DNA $(O)$.

$0.3 \%$ Eugon broth and $3 \mathrm{~mm}-\mathrm{CaCl}_{2}$ for $15 \mathrm{~min}$. at room temperature, or by washing them in the cold with $0.3 \mathrm{M}-\mathrm{NaCl}+0.3 \%$ Eugon broth $(\mathrm{w} / \mathrm{v})$. Washing of DNasetreated suspensions with $0.3 \mathrm{M}-\mathrm{NaCl}$ broth did not remove significant amounts of radioactive label. Similarly, washing of suspensions prewashed with $0.3 \mathrm{M}-\mathrm{NaCl}$ broth with DNase did not result in a further significant release of radioactivity. We therefore routinely treated the bacteria with $0.3 \mathrm{M}-\mathrm{NaCl}$. The cells were washed once more in the cold with O.I M-NaCl in Eugon broth and finally suspended in L-broth. The uptake of phage $\lambda$ DNA can be very rapid under these conditions (Fig. I).

Reisolation of adsorbed DNA. Bacteria exposed to radioactive phage $\lambda$ DNA were centrifuged and resuspended in SSC at $\mathrm{pH} 9$ containing $0.5 \%$ sodium lauryl sulphate and $0.1 \mathrm{mg} . / \mathrm{ml}$. of pronase. $\mathrm{NaCl}$ was added after $60 \mathrm{~min}$. at $37^{\circ}$ to make the extract $\mathrm{I} \cdot \mathrm{O}$ M. It was then shaken with chloroform, centrifuged and the supernatant dialysed against SSC. Recovery of the radioactivity was always complete. 


\section{RESULTS}

Irreversible adsorption of phage $\lambda D N A$. Competent bacteria of culture 66 were exposed for $5 \mathrm{~min}$. to increasing amounts of ${ }^{32} \mathrm{P}$-labelled phage $\lambda$ DNA. They were then washed free of reversibly bound radioactivity with $0.3 \mathrm{M}-\mathrm{NaCl}$ in Eugon broth and assayed for ${ }^{32} \mathrm{P}$-activity. A linear increase of irreversibly bound phage $\lambda$ DNA was obtained up to a value of about 40 molecules/cell (Fig. 2). Since only one-third of the radioactivity had been taken up, each cell bound an average of $13 \lambda$ DNA molecules. Using an excess of cells of culture 66 only 30 to $40 \%$ of the DNA from our phage $\lambda$ DNA preparations was irreversibly bound. We did not investigate the properties of the unadsorbed DNA and we have at present no explanation.

\section{Table I. Adsorption of phage $\lambda D N A$ by various cultures of Haemophilus influenzae strain $R d$}

\begin{tabular}{|c|c|c|c|}
\hline \multirow[b]{2}{*}{ Cultures* } & \multicolumn{3}{|c|}{ Adsorbed DNA as $\%$ of total label added } \\
\hline & Initially & Reversibly & Irreversibly \\
\hline${ }_{138} \mathrm{Rd}\left(\mathrm{HP}_{\mathrm{I}}\right)^{+}$ & 98 & 60 & 33 \\
\hline I43 Rd & 98 & 72 & 30 \\
\hline 62 Rd HP I-r & 98 & 61 & 37 \\
\hline 6662 nov-r HP I-r & 99 & 57 & 42 \\
\hline 207 I43 HP I $-s$ & 28 & 22 & 8 \\
\hline 200 I 43 str-r HP I-s & 32 & 15 & 15 \\
\hline 216200 nov-r HP I-s & 34 & 15 & I5 \\
\hline $208207 \mathrm{HP}_{\mathrm{I}-s}\left(\mathrm{HP}_{\mathrm{I}}\right)^{+}$ & 30 & 16 & 8 \\
\hline $2 \mathrm{I}_{4} 200$ str-r HP I-s $\left(\mathrm{HP}_{\mathrm{I}}\right)^{+}$ & 16 & 10 & 8 \\
\hline I97 I43 str-r HP I $r$ (HP I) ${ }^{+}$ & 32 & 12 & I8 \\
\hline 217200 str-r HP I-r & 33 & 24 & 8 \\
\hline 66 Growing & 98 & 92 & 10 \\
\hline 66 Anaerobic & 97 & $8 I$ & IO \\
\hline 66 Competent & 98 & 55 & $4 \mathrm{I}$ \\
\hline
\end{tabular}

* Unless otherwise indicated all cultures were competent.

To determine whether adsorbed phage $\lambda$ DNA can block subsequent uptake of homologous DNA, competent bacteria were exposed for $5 \mathrm{~min}$. to increasing amounts of radioactive phage $\lambda$ DNA and then diluted tenfold in excess transforming DNA at $2 \times 10^{9}$ streptomycin resistance markers $/ \mathrm{ml}$. The suspensions were shaken for $15 \mathrm{~min}$. at room temperature and then analysed. There was a decline in subsequent transformation which correlated strongly with the exposure to increasing amounts of phage $\lambda$ DNA (Fig. 2). We feel that adsorbed $\lambda$ DNA can therefore prevent uptake of homologous DNA.

When a number of our cultures were tested for their capacity to bind irreversibly $\lambda$ DNA, it was found that a large group was very much less efficient in doing so (Table I). The efficient group consisted of cultures 138 and 143 and all derivatives of culture 62. These have in common that they are either absolutely resistant to phage HPI or that they seem to be partially resistant, i.e. they give very turbid plaques with this phage. The very much less efficient group consists exclusively of derivatives of a streptomycin-resistant transformant of culture 143 which was picked because it gave consistently clear plaques with phage HPI. The latter group includes non-lysogens as well as HPI lysogens, phage-sensitive as well as spontaneous phage-resistant mutants, 
antibiotic-resistant as well as antibiotic-sensitive cultures (Table I). The phage resistance marker in culture 62 derivatives cotransforms with the nov-r marker just as frequently as does the phage resistance marker in the derivatives of culture 200 (Stuy, 1968). We believe that the two phage resistance markers are allelic if not identical and thus neither one may be implicated in the reduced or enhanced capacity of irreversibly binding phage $\lambda$ DNA.

Investigating reversible adsorption of phage $\lambda$ DNA we observed that both groups of cultures also exhibited quite different efficiencies (Table I). We have preliminary data which suggest that the two groups also show different efficiencies in reversible binding of homologous DNA. We think therefore that it is quite possible that reported variations in DNA uptake are due to different cultures used.

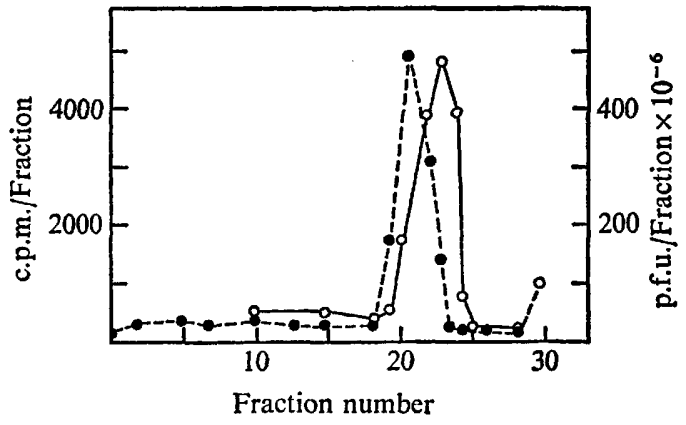

Fig. 3

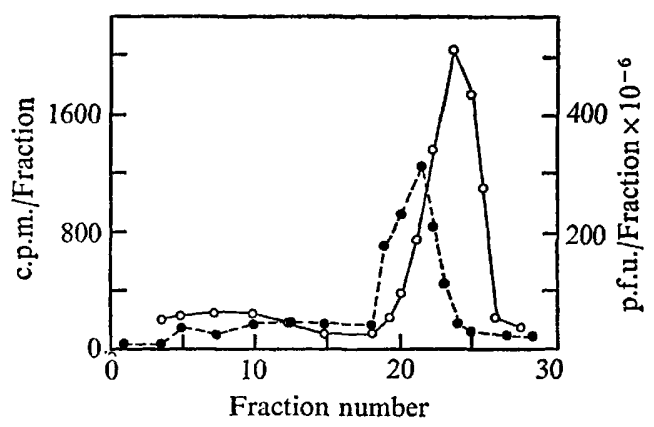

Fig. 4

Fig. 3. Distribution of ${ }^{32}$ P-labelled phage $\lambda$ DNA (O) and phage HPI DNA (O; both I $\mu$ g.) after $2.5 \mathrm{~h}$. centrifugation in a SW 39 rotor at $4^{\circ}$ and $30,000 \mathrm{rev} . / \mathrm{min}$. in a 5 to $20 \%$ sucrose density gradient ( $\mathrm{M}-\mathrm{NaCl}, \mathrm{O} \cdot \mathrm{OI} \mathrm{M}-\mathrm{Na}$-citrate, I mM-EDTA, $\mathrm{I}$ mM-tris at $\mathrm{pH} 7.0$ ).

Fig. 4. Distribution of phage HPI DNA (O) and of ${ }^{32} \mathrm{P}$-labelled phage $\lambda$ DNA reisolated after $15 \mathrm{~min}$. incubation from Haemophilus influenzae Rd culture $66(\odot)$, after centrifugation in a 5 to $20 \%$ sucrose gradient.

Fate of adsorbed phage $\lambda D N A$. Irreversibly bound phage $\lambda$ DNA is very slowly broken down into acid-soluble products during incubation of DNA-treated cells in L-broth at $37^{\circ}$. Radioactivity released into the medium was always found to be acidsoluble. At no time did the bacteria themselves contain significant amounts of acidsoluble radioactivity. Degradation to very small products was negligible at $20 \mathrm{~min}$. of incubation; it then increased slowly to about $20 \%$ of adsorbed radioactivity at $60 \mathrm{~min}$. and to about $30 \%$ at IIO min. of incubation. This breakdown is quite slow when compared to the degradation of irreversibly bound transforming DNA (Stuy \& van der Have, 1971).

Irreversibly bound phage $\lambda$ DNA, reisolated after $0,5,10,15$ or $60 \mathrm{~min}$. of incubation of DNA-treated bacteria, always banded in $\mathrm{CsCl}$ density gradient centrifugation at the position characteristic for $\lambda$ DNA. We observed no radioactivity at the position typical for single-stranded $\lambda$ DNA. These observations thus give no indication of gross alterations in the adsorbed $\lambda$ DNA.

Phage $\lambda$ DNA sediments slightly faster in a 5 to $20 \%$ sucrose density gradient than phage HPI DNA (Fig. 3). Reisolated $\lambda$ DNA sedimented under these conditions with normal or with only slightly reduced velocity (Fig. 4). These observations indicate that there was no extensive double-stranded breakage of the bound $\lambda$ DNA. 
Expression of bound phage $\lambda D N A$. Competent bacteria of a non-lysogenic culture 66 and of HP1 lysogenic culture 138 were exposed to phage $\lambda$ DNA for 5 min. The uptake for both cultures was found to be about 3 DNA molecules/cell. The bacteria were washed, resuspended in L-broth and exposed to $800 \mathrm{erg} / \mathrm{mm}^{2}$. of u.v. radiation. Irradiation causes eventual lysis of culture 66 and induction and lysis of culture I 38 . It was reasoned that lysis would ensure release of any $\lambda$ DNA molecules or $\lambda$ phage particles formed. The radiation dose has no effect on the transfection of Haemophilus influenzae with phage HPI DNA (A. Rosenthal, personal communication). Both cultures lysed after Ioo min. Both lysates contained about $70 \%$ acid-insoluble radioactivity. The lysate from culture 138 contained $1 \cdot 2 \times 10^{11}$ HPI phage/ml. Neither lysate contained $\lambda$ phage particles nor infectious $\lambda$ DNA. Phage $\lambda$, or $\lambda$ DNA, added to the lysates, was subsequently fully recovered. Thus the lysates did not seem to contain substances interfering with the respective assays. Irreversibly bound $\lambda$ DNA does not seem to be expressed under these conditions.

In subsequent experiments, DNA-treated bacteria were incubated without exposure to $u . v$. radiation. Cells were lysed after $100 \mathrm{~min}$. of incubation and the $\lambda$ DNA reisolated. It was found to have lost all of its biological activity.

\section{DISCUSSION}

The experiments described demonstrate that cultures of Haemophilus influenzae vary in the extent to which they irreversibly bind significant amounts of (foreign) phage $\lambda$ DNA. The cultures fall into two groups, an inefficient group and a relatively efficient group. We have not been able to correlate this difference with any other cell property. Since both groups of cultures adsorb transforming DNA and transfecting phage HPI DNA equally well (unpublished results), the bacteria may possess an uptake system that can recognize homologous DNA.

Irreversibly bound phage $\lambda$ DNA seems rather inert, i.e. its breakdown to acidsoluble products is slow when compared to that of adsorbed homologous DNA (Stuy \& van der Have, 1971). This may also be a consequence of recognition of homologous DNA. Most, if not all, of the acid-soluble degradation products were found in the medium and little, if any, in the bacteria themselves. This indicates that degradation may take place outside the cell.

When DNA-treated Haemophilus influenzae bacteria were incubated under growth conditions, adsorbed phage $\lambda$ DNA retained some of its macromolecular properties for considerable periods. For example, its specific density in $\mathrm{CsCl}$ remained virtually unaltered and its sedimentation velocity in linear sucrose gradients was only slightly reduced. Steinhart \& Herriott (1968) observed similar results for adsorbed Escherichia coli DNA. It is concluded that foreign DNA can remain associated with $H$. influenzae bacteria for considerable periods. The loss of biological activity within an hour is indicative, however, of some degradation.

We have found no evidence of expression of adsorbed phage $\lambda$ DNA. This is perhaps not surprising since we looked for very advanced products such as whole $\lambda$ DNA molecules and whole $\lambda$ phage particles. We are now trying to establish whether there is any $\lambda$-specific mRNA production under these conditions. 
C. M. N. was a recipient of a National Institute of Health Genetics Training grant no. I7-9ro stipend, and the work was in partial fulfilment of a M.Sc. degree.

This study was in part supported by the United States Atomic Energy Commission grant contract no. AT-(40-I)-3885.

After this manuscript was completed, two publications appeared concerning a restriction enzyme present in Haemophilus influenzae strain Rd (Kelly \& Smith, 1970; Smith \& Wilcox, 1970). This enzyme does not degrade homologous DNA but causes double-strand breaks in phage $\mathrm{T}_{7}$ and $\mathrm{P}_{22}$ DNA at a small number of sites. This enzyme is thus able to recognize foreign DNA. We do not know how this enzyme affects uptake of foreign DNA or whether it degrades phage $\lambda$ DNA. Apparently it did not act efficiently on irreversibly bound $\lambda$ DNA.

\section{REFERENCES}

BARNHART, B. J. (1965). Kinetics of bacteriophage $\lambda$ deoxyribonucleic acid infection in Escherichia coli. Journal of Bacteriology 90, 1617-1623.

KAISER, A. D. \& Hogness, D. S. (I960). The transformation of Escherichia coli with deoxyribonucleic acid isolated from bacteriophage $\lambda \mathrm{dg}$. Journal of Molecular Biology 2, 392-4I 5 .

Kelly, T. J., JUN. \& SMITH, H. O. (1970). A restriction enzyme from Haemophilus influenzae. II. Base sequence of the recognition site. Journal of Molecular Biology 5I, 393-409.

LACKS, S., Greenberg, B. \& Carlson, K. (I967). Fate of donor DNA in pneumococcal transformation. Journal of Molecular Biology 29, 327-347.

Lerman, L. S. \& Tolmach, L. J. (I957). Genetic transformation. I. Cellular incorporation of DNA accompanying transformation in Pneumococcus. Biochimica et biophysica acta 26, 68 .

Pene, J. J. \& Romig, W. R. (I964). On the mechanism of genetic recombination in transforming Bacillus subtilis. Journal of Molecular Biology 9, 236-245.

SCHAeffer, P. (1958). Interspecific reactions in bacterial transformation. Symposia of the Society for Experimental Biology 12, 60-74.

Smith, H. O. \& Wilcox, K. W. (1970). A restriction enzyme from Haemophilus influenzae. I. Purification and general properties. Journal of Molecular Biology 51, 379-39I.

Steinhart, W. L. \& Herriott, R. M. ( 1968 ). Genetic integration in the heterospecific transformation of Haemophilus influenzae cells by Haemophilus parainfluenzae deoxyribonucleic acid. Journal of Bacteriology 96, 1725-173I.

Stuy, J. H. (1962). Transformability of Haemophilus influenzae. Journal of General Microbiology 29, $537-549$.

Stuy, J. H. (1968). Phage resistance in Haemophilus influenzae. Biochemical and Biophysical Research Communications 33, 682-687.

STuY, J. H. (1969). Prophage mapping by transformation. Virology 38, 567-572.

STUY, J. H. \& VAN DER Have, B. (I97I). Degradation of adsorbed transforming DNA by Haemophilus influenzae. Journal of General Microbiology 65, 147-1 52.

StuY, J. H. \& STERN, D. (I964). The kinetics of DNA uptake by Haemophilus influenzae. Journal of General Microbiology 35, 39I-400. 